\title{
O PRINCÍPIO DA INSIGNIFICÂNCIA: UMA FONTE DO DIREITO QUE LIMITA E LEGITIMA PRERROGATIVAS
}

Ricardo Claret Pitondo Filho

ISSUE DOI: $10.21207 / 1983.4225 .303$

\section{RESUMO}

O presente artigo tem por objetivo abordar a aplicação do princípio da insignificância, no passado e atualmente, o qual tem se mostrado uma fonte diretriz no campo de incidência do Direito Penal, na medida em que estabelece um equilíbrio entre a atuação sancionadora do Estado e o direito de liberdade do acusado. Imperioso registrar que, desde a monarquia romana, enraizada nos moldes do Direito Privado, o envoltório deste instrumento jurídico já era formado, e, após o advento do brocardo latino "minima non curat praetor", ficou estampado que a sociedade já demonstrava sua aversão pela intervenção do juiz (pretor) às causas ou delitos de bagatela. Hodiernamente, esta ideia não é diferente, tendo o doutrinador alemão, Claus Roxin, a partir do ano de 1964, delimitado com propriedade o assunto, fazendo com que os reflexos de seus estudos atingissem a jurisprudência brasileira, que conta, inclusive, com a concordância da Suprema Corte, a qual fixou requisitos ao campo de abrangência do princípio. Muito embora haja críticas acerca da existência e conseguinte aplicação da insignificância, não se pode olvidar que o princípio estudado 
seja uma fonte do direito que, sobretudo, norteia a aplicação da justiça no caso concreto.

Palavras-chave: Direito Penal. Princípios. Crime. Bagatela. Tipicidade material.

\section{EVOLUÇÃO HISTÓRICA}

Não se pode ignorar que o Direito Romano é uma referência na aplicabilidade do princípio da insignificância. É nele que foram feitas as primeiras menções ao sobredito princípio, pois, naquela época, o julgador (pretor) de modo geral não se atentava às causas ou condutas de bagatela, consoante a máxima contida no brocardo "minima non curat pretor", focando-se a resolver tão somente as lides e os impasses de maior relevância social.

Salienta-se que, segundo o professor Élcio Arruda ${ }^{159}$, desde a monarquia romana, mesmo antes da época dos pretores (356 a.C.), a Lei das XII Tábuas (451-449 a.C.) reservava a intervenção penal a violações que diretamente atentassem contra o Estado (alta traição, subtração ao serviço militar, incitação ao inimigo etc.). O direito romano distinguia entre infrações penais privadas ("delicta privata") e públicas ("crimina publica"): aquelas, menos graves, entregues à persecução do próprio ofendido, em tribunais civis; estas, de maior intensidade, cometidas à acusação por parte de qualquer do povo, com a obrigatoriedade de o tribunal criminal emitir o veredicto condenatório ou absolutório. Nesta época, havia desde logo uma diretiva clara que informava o sistema: lesões de menor relevância deveriam ser equacionadas entre os próprios envolvidos, sem a ingerência do poder público. Assim, criou-se a expressão "minimis non curat praetore".

Contudo, deve-se considerar que, atualmente, a doutrina tem entendido que o Direito Romano foi notadamente desenvolvido sob a ótica do Direito Privado e não do Direito Público, razão pela qual o referido brocardo carece de lastro principiológico, sendo um mero aforismo da época, servindo tão somente como referência, mas não como via de reconhecimento do princípio da insignificância. É, pois, precipitado atribuir

${ }^{159}$ ARRUDA, Élcio. Insignificância: um princípio nada insignificante. Boletim IBCCRIM : São Paulo, ano 17, n. 202, p. 12-14, set. 2009. 
aos Romanos tal crédito, uma vez que não tinham a noção da legalidade penal, princípio intrinsecamente vinculado ao da insignificância.

Segundo levantamentos históricos e entendimento de parte da doutrina, o princípio da insignificância, ou a criminalidade de bagatela, surgiu estampado com o caráter da patrimonialidade na Europa, mais precisamente após a Primeira Guerra Mundial e, principalmente, após o final da Segunda, ocasião em que se verificou uma eclosão de delitos patrimoniais consistentes em saques nas cidades e subtrações de pequena relevância, vindo daí a primeira nomenclatura doutrinária de "criminalidade de bagatela".

A sobredita nomenclatura, qual seja, "criminalidade de bagatela", foi dada àqueles crimes que não causavam graves lesões ao bem jurídico tutelado pelo direito, no caso o patrimônio, e, de acordo com os estudiosos, não deveriam ser apreciados pelo poder judiciário, já que não afetavam o convívio em sociedade.

Necessário dizer que Claus Roxin, doutrinador alemão e primeiro a estudar o tema, em 1964, desenvolve o princípio da insignificância com maior propriedade e delimitações, tendo como base a destituição de determinadas condutas humanas de tipicidade material e cuja origem fática está intrinsecamente ligada à questão da patrimonialidade, partindo do velho brocardo latino "mínima non curat praetor". No seu entender, em sendo ínfimo o dano causado ao patrimônio, a conduta não constitui fato típico e, consequentemente, falta-lhe elemento determinante para que seja classificado como crime.

Ivan Luiz da Silva faz menção a Roxin, quanto à formulação principiológica da insignificância:

O recente aspecto histórico do Princípio da Insignificância é, inafastavelmente, devido a Claus Roxin, que, no ano de 1964, o formulou com base de validez geral para determinação geral do injusto, a partir de considerações sobre a máxima latina mínima non curat praetor. ${ }^{160}$

${ }^{160}$ SILVA, Ivan Luiz da. Princípio da insignificância no direito penal brasileiro. Curitiba: Juruá, 2006. p. 87. 
Destarte, o princípio em questão é tido como meio de interpretação restritiva dos delitos, valorizando, desta forma, o caráter fragmentário do direito penal.

Consigna-se que a evolução do princípio da insignificância está intimamente relacionada ao princípio da legalidade, que se deu a partir do movimento iluminista e da propagação do individualismo político. Este, inclusive, é o raciocínio de Maurício Antônio Ribeiro Lopes, que diz que "o princípio da legalidade é o tronco-mãe de onde brotam vários ramos (princípios decorrentes) - com maior ou menor grau de dependência das forças hauridas pela seiva do tronco-mãe."161

Salienta-se que, no momento em que o princípio da legalidade foi agregado às constituições inglesa e americana, foi também aderido a ele, de forma implícita, o princípio da insignificância.

Também na França, com a Declaração Universal dos Direitos do Homem e do Cidadão, proclamada em 1789, foi acolhido o principio da legalidade, juntamente com o da insignificância, tendo sido expresso, em seu artigo $5^{\circ}$, que a lei não proíbe senão as ações nocivas à sociedade.

Assim, o principio da insignificância tem sido aplicado aos casos em que há ínfima afetação do bem jurídico protegido, quando o conteúdo do injusto é tão pequeno que não subsiste qualquer razão para que seja aplicada a sanção penal. Ele está, também, intimamente ligado ao ideal de proporcionalidade que a pena deve guardar em relação à gravidade do dano causado pela conduta, onde a mínima sanção aplicada ao caso seria desproporcional à significância material do fato.

\section{CONCEITO}

Nos mais diversos ramos do mundo jurídico, paulatinamente, ganha fôlego a evocação do princípio da insignificância como veículo hábil para excluir "bagatelas" do tratamento ortodoxo ditado pelo sistema. Em verdade, "a adequada conformação do princípio da insignificância é tudo, menos algo insignificante". ${ }^{162}$

${ }^{161}$ LOPES, Mauricio Antônio Ribeiro. Principio da insignificância no direito penal. São Paulo: Revista dos Tribunais, 1997. p. 40.

${ }^{162}$ ARRUDA, Élcio. Insignificância: um princípio nada insignificante. Boletim IBCCRIM. São Paulo, ano 17, n. 202, p. 12-14, set. 2009. 
O princípio da insignificância tem-se mostrado assunto cada vez mais em voga no mundo jurídico, já que, consoante os ensinamentos de ROXIN, "uma ordem jurídica sem justiça social não é um Estado de direito material, e tampouco pode utilizar-se da denominação de Estado Social um Estado planejador e providencialista que não acolha as garantias de liberdade do Estado de Direito"163

Sabe-se que toda ciência, quer seja jurídica ou não, tem como alicerce princípios que orientam todos os seus demais fundamentos, a fim de sustentar a veracidade das suas posições e postulados elaborados. Neste ínterim, os princípios nada mais são do que ferramentas dadas às mãos dos cientistas que, devidamente trabalhadas, são a base de toda construção de um sistema.

Acerca do assunto, Maurício Antonio Ribeiro Lopes assevera:

O que define algo como princípio é precisamente sua capacidade de superar os limites de sua força interna para irradiar comandos operadores do funcionamento de estruturas alheias ao próprio ser. O princípio projeta sua relevância sobre a existência de outros seres, por isso seu caráter transcendental, superior e vinculante. ${ }^{164}$

Desta forma, considerando que os princípios são como definidores de todo o sistema, conclui-se ser muito mais grave transgredir um princípio do que uma norma, pois assim agindo ofende-se não apenas um mandamento obrigatório específico, mas o conjunto sistêmico todo.

Na ciência do Direito Penal não é diferente. Por se tratar de uma norma jurídica, o Direito Penal não se exaure em seu texto legal, havendo, pois, princípios jurídicos implícitos decorrentes do sistema jurídico, os quais são adotados para sanar lacunas que o legislador não consegue preencher. Daí a existência do principio da insignificância, onde se busca preencher um vácuo ainda existente no ordenamento jurídico pátrio condizente à aplicação do direito de punir do Estado nos crimes de bagatela.

${ }^{163}$ ROXIN, Claus. Política Criminal e Sistema Jurídico-Penal, tradução Luís Greco. São Paulo:Editora Renovar, 2000, p.20.

${ }^{164}$ LOPES, Mauricio Antonio Ribeiro Lopes. Princípio da insignificância no direito penal. São Paulo: Ed. Revista dos Tribunais, 1997. p. 31. 
Cumpre dizer que não existe, na dogmática jurídica, nenhum instrumento legislativo ordinário ou constitucional que defina ou acate formalmente o princípio da insignificância, razão pela qual este pode ser inferido na exata proporção em que se aceitam limites para a interpretação constitucional e das leis em geral.

Assim, o conceito do referido princípio é de criação exclusivamente doutrinária e pretoriana e, em razão da tônica conservadorista do Direito, sua aplicação sofre graves dificuldades no mundo jurídico. Em verdade, o que existe acerca do assunto é uma interpretação doutrinária e jurisprudencial que permite delimitar as condutas tidas como insignificantes, sob a ótica de um direito penal mínimo, subsidiário e fragmentário.

Dentre os doutrinadores, pode-se destacar a conceituação de Diomar Ackel Filho:

O princípio da insignificância pode ser conceituado como aquele que permitir infirmar a tipicidade dos fatos que, por sua inexpressividade, constituem ações de bagatela, despidas de reprovabilidade, de modo a não merecerem valoração da norma penal, exsurgindo, pois, como irrelevantes. ${ }^{165}$

Nesta mesma linha de raciocínio, a jurisprudência entende ser o principio da insignificância um instrumento da politica-criminal por meio do qual algumas condutas consideradas inicialmente típicas podem ser excluídas da apreciação do Direito Penal, dada a irrelevância da ofensa ao bem jurídico tutelado pelo Estado, conforme se vê:

O princípio da insignificância surge como instrumento de interpretação restritiva do tipo penal que, de acordo com a dogmática moderna, não deve ser considerado apenas em seu aspecto formal, de subsunção do fato à norma, mas, primordialmente, em seu conteúdo material, de cunho valorativo, no sentido da sua efetiva lesividade ao bem jurídico tutelado pela norma penal, consagrando os

165 ACKEL FILHO, Diomar. O princípio da insignificância no direito penal. Revista de jurisprudência do tribunal de alçada criminal de São Paulo. TJSP, v. 94, p. 72-77. 
postulados da fragmentariedade e da intervenção mínima. Indiscutível a sua relevância, na medida em que exclui da incidência da norma penal aquelas condutas cujo desvalor da ação e/ou do resultado (dependendo do tipo de injusto a ser considerado) impliquem uma ínfima afetação ao bem jurídico. (HC n. 67.905/SP, Rel. Ministro ARNALDO ESTEVES LIMA, j. em 7-8-2008). ${ }^{166}$

O Supremo Tribunal Federal, de maneira reiterada, tem usufruído da prerrogativa deste princípio, tendo formulado o seguinte conceito sobre o tema:

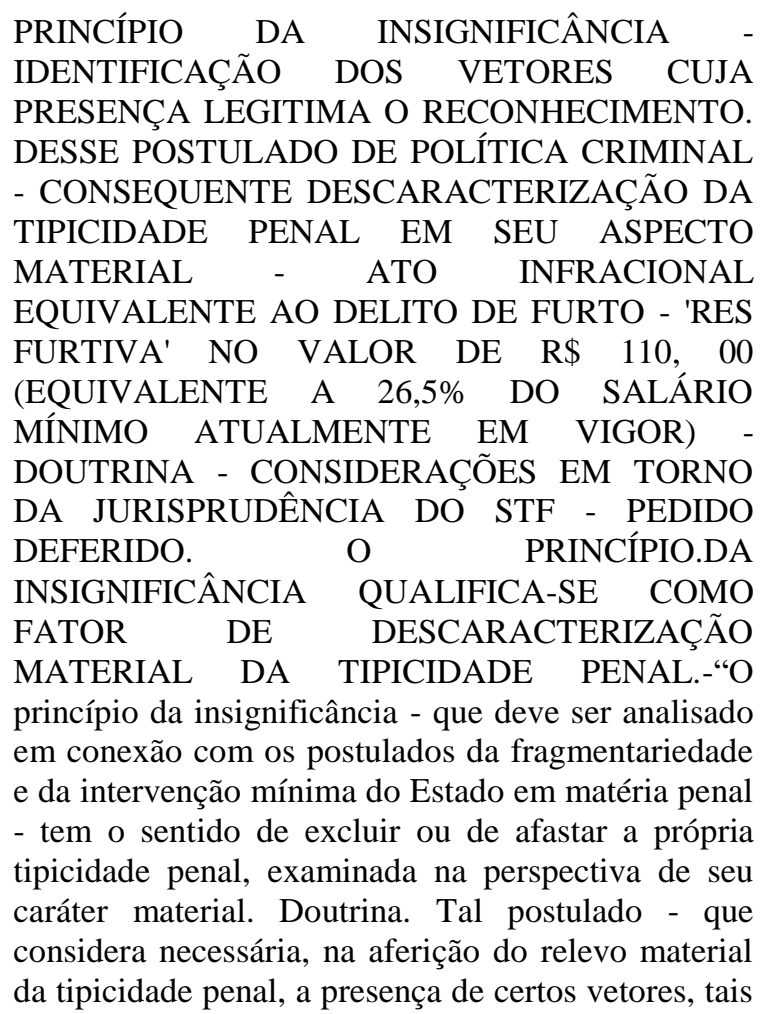

166 BRASIL. Superior Tribunal de Justiça. HC n. 67.905/SP, Rel. Ministro ARNALDO ESTEVES LIMA, julgado em 7.8.2008 
como (a) a mínima ofensividade da conduta do agente, (b) a nenhuma periculosidade social da ação, (c) o reduzidíssimo grau de reprovabilidade do comportamento e (d) a inexpressividade da lesão jurídica provocada - apoiou-se, em seu processo de formulação teórica, no reconhecimento de que o caráter subsidiário do sistema penal reclama e impõe, em função dos próprios objetivos por ele visados, a intervenção mínima do Poder Público. "O POSTULADO DA INSIGNIFICÂNCIA E A FUNÇÃO DO DIREITO PENAL: 'DE MINIMIS, NON CURAT PRAETOR'."- O sistema jurídico há de considerar a relevantíssima circunstância de que a privação da liberdade e a restrição de direitos do indivíduo somente se justificam quando estritamente necessárias à própria proteção das pessoas, da sociedade e de outros bens jurídicos que lhes sejam essenciais, notadamente naqueles casos em que os valores penalmente tutelados se exponham a dano, efetivo ou potencial, impregnado de significativa lesividade. 'O direito penal não se deve ocupar de condutas que produzam resultado, cujo desvalor por não importar em lesão significativa a bens jurídicos relevantes - não represente, por isso mesmo, prejuízo importante, seja ao titular do bem jurídico tutelado, seja à integridade da própria ordem social (HC n. 94.505/RS, Rel. Ministro CELSO DE MELLO, j. em 16-9-2008). ${ }^{167}$

Assim, apesar da falta de expressa previsão legal, não se pode olvidar que o princípio da insignificância tem sua aplicação legitimada pelo sistema penal contemporâneo por ajustar-se à equidade, evitando que se cometam graves injustiças, a fim de que se possa isentar da reprimenda penal o autor da conduta que, por sua irrelevância, não atenta contra os valores sociais resguardados pela norma penal.

Ao se fazer a análise acerca da importância deste princípio doutrinário e jurisprudencial no Direito Penal, verifica-se o sentimento de justiça e de valores vigentes em uma sociedade pertencente a um Estado

${ }^{167}$ BRASIL. Supremo Tribunal Federal. HC n. 94.505/RS. Habeas Corpus. Rel. Ministro CELSO DE MELLO, julgado em 16-9-2008. 
Democrático de Direito, que não se preocupa com a ação que, por sua inexpressividade, não chega a ofender os bens abrangidos pela norma penal.

Nos dizeres de Francisco de Assis Toledo, primeiro jurista pátrio a observar a incidência do princípio da insignificância, é certo que "o direito penal, por sua natureza fragmentária, só vai até onde seja necessário para a proteção do bem jurídico, não deve preocupar-se em bagatelas" $" 168$.

Neste ínterim, o princípio da insignificância é aplicável aos casos em que há ínfima afetação ao bem jurídico, quando o conteúdo do injusto é tão pequeno que não subsiste qualquer razão para que seja aplicada a sanção penal. Ele está intimamente ligado, também, ao ideal de proporcionalidade que a pena dever guardar em relação à gravidade do dano causado pela conduta, na qual a mínima sanção aplicada ao caso seria desproporcional à significância material do fato.

Ao seu turno, Manãs, ao tratar sobre o tema, conceitua o princípio ora examinado da seguinte maneira:

O princípio da insignificância é um instrumento de interpretação restritiva, fundado na concepção material do tipo penal, por intermédio do qual é possível alcançar, pela via judicial e sem macular a segurança jurídica do pensamento sistemático, a proposição politico-criminal da necessidade de descriminalização de condutas que, embora formalmente típicas, não atingem de forma relevante os bens jurídicos protegidos pelo direito penal. ${ }^{169}$

Prado considera o princípio da insignificância um basilar do Direito Penal Democrático, e o define nos seguintes termos:

Pelo princípio da insignificância, formulado por Claus Roxin e relacionado com o axioma minima

168 TOLEDO, Francisco de Assis. Princípios básicos de direito penal: de acordo com a lei $\mathrm{n}^{\circ}$ 7209, de 11-7-1984 e com a Constituição Federal de 1988. 4 ed. São Paulo: Saraiva, 1991. p. 133.

${ }^{169}$ MAÑAS, Carlos Vico. O princípio da insignificância como excludente de tipicidade no direito penal. São Paulo: Saraiva, 1994. p.81. 
non curat praetor, enquanto manifestação contrária ao uso excessivo da sanção criminal, devem ser tidas como atípicas as ações ou omissões que afetem infimamente um bem jurídico-penal. A irrelevante lesão do bem jurídico protegido não justifica a imposição de uma pena, devendo excluir-se a tipicidade em caso de danos de pouca importância. ${ }^{170}$

Assim, a irrelevância ou insignificância de determinada conduta deve ser aferida não apenas em relação à importância do bem juridicamente atingido, mas, especialmente, em razão da extensão da lesão produzida, devendo, assim, ser valorada em consonância com a ordem jurídica global.

O mencionado princípio é, pois, uma especial maneira de se exigir a composição do tipo penal a ser preenchido, doravante não apenas por aspectos formais, mas também, e essencialmente, por elementos objetivos que levam à percepção da utilidade e da justiça de imposição de pena criminal ao agente.

Ante a conceituação oferecida pelos doutrinadores supra, bem como com escopo na jurisprudência dos Tribunais, verifica-se que o princípio da insignificância funciona verdadeiramente como um instrumento de interpretação restritiva do tipo penal, determinando-se a exclusão da lei penal daquelas condutas formalmente típicas que, no caso em concreto, em razão de sua escassa lesividade, não demonstram relevância jurídica para o Direito Penal, já que não se pode fazer apenas um juízo formal da conduta típica praticada pelo agente.

Consigna-se que a aplicação do principio da insignificância não consiste em deixar de aplicar a lei penal no caso sub judice, mas sim de aplicá-la de maneira correta e justa, restringindo a amplitude abstrata do tipo penal prevista pelo legislador, de forma a alcançar o caráter material de justiça.

Assim, com base nos ensinamentos de Ackel, pode-se concluir que:

${ }^{170}$ PRADO, Luiz Regis. Curso de direito penal brasileiro: parte geral, arts. $1^{\circ}$ a 120. São Paulo: Ed. Revista dos Tribunais, 2005. p. 154. 
O princípio da insignificância se ajusta à equidade e correta interpretação do Direito. Por aquela, acolhese um sentimento de justiça, inspirado nos valores vigentes em uma sociedade, liberando-se o agente, cuja ação, por sua inexpressividade, não chega a atentar contra os valores tutelados pelo Direito Penal. Por esta, se exige uma hermenêutica mais condizente do direito, que se não pode ater a critérios inflexíveis de exegese, sob pena de se desvirtuar o sentido da própria norma e conduzir a graves injustiças. Se o juiz aplica (o Direito) de forma matemática, como um formalismo intransigente, fazendo justiça mesmo que pereça o mundo, distancia-se, destarte, da realidade humana. O silogismo, em hipótese alguma, pode ser rígido. É necessário um perfeito equilíbrio na sua atuação e na utilização nas sentenças judiciárias. A interpretação, com base em critérios de razoabilidade, desconsidera um determinado fato como obra criminosa, valorizando-o como insignificante e, portanto, destituído de reprovabilidade, de modo a obstar que possa se subsumir num "standart" de tipicidade da lei penal ${ }^{171}$.

Portanto, a insignificância tem o condão de fazer justiça no caso concreto, não deixando incidir apenas a justiça formal, mas também a justiça material.

\subsection{Princípio da legalidade}

171 ACKEL FILHO, Diomar. O princípio da insignificância no direito penal. Revista de jurisprudência do Tribunal de Alçada Criminal de São Paulo. TJSP, v. 94, p. 73-74. 
O princípio da insignificância está intrinsicamente ligado ao princípio da legalidade, previsto constitucionalmente no artigo $5^{\circ}$, XXXIX, e contido na máxima latina "nullun crimen, nulla poena sine lege", que garante que a elaboração de normas incriminadoras seja realizada exclusivamente pela lei, sendo que nenhuma ação poderá ser considerada criminosa e nem suscetível de pena criminal senão por conta de uma lei anterior que a defina como tal, e que lhe comina a sanção correspondente.

A função do principio da legalidade é fazer com que haja uma seleção prévia e um rol taxativo dos comportamentos humanos considerados crimes passíveis de repressão penal. A este principio é instituída a função limitadora do ius puniendi, a fim de garantir a segurança jurídica do cidadão, na medida em que se estabelece que o agente não poderá ser punido senão em virtude da lei, que deverá definir precisa e claramente qual a conduta proibida pelo direito.

Neste Ínterim, apenas o poder Legislativo tem a faculdade de estabelecer normais penais, elucidando em lei, no seu sentido estrito, a definição dos crimes e suas conseguintes sanções. Assim, a Constituição estabeleceu ao Poder Legislativo, órgão máximo de expressão da soberania popular, a prerrogativa de elaborar leis, as quais devem ser feitas conforme os preceitos definidos na Constituição e pautar-se nos critérios de proporcionalidade e razoabilidade.

Data Venia, a técnica legislativa não pode utilizar-se de cláusulas gerais para a definição da conduta típica, pois é capaz de ameaçar a segurança social e instaurar o regime de arbitrariedade judicial. É mister que o legislador faça a definição clara do fato criminoso, sem impingirlhe significado subjetivo, delimitando atributos essenciais e específicos da conduta humana, de forma a torná-la inconfundível com outra.

Destarte, em que pese o fato de o princípio da legalidade ser imprescindível ao Estado Democrático de Direito, o Direito Penal contemporâneo não mais subsume-se com o aspecto meramente formalista do crime, razão pela qual o ato ilícito não deve mais ser entendido como simples realização do modelo abstrato previsto em lei (subsunção formal), uma vez que tipicidade formal, por si só, não é suficiente para tanto, devendo-se associar a esta o conteúdo da tipicidade material.

Hodiernamente, construiu-se um novo preceito denominado "nullum crimen nulla poena sine iuria", ou seja, não existe nem pena sem que haja dano relevante ao bem jurídico tutelado penalmente. Dessa for- 
ma, a ação deve, necessariamente, ter relevância social e acarretar um resultado significante, causando considerável prejuízo ao bem jurídico protegido, para que seja considerada criminosa e possível de sanção.

Neste sentido, aliás, são as lições do insigne doutrinador Cássio Lazzari Prestes:

O Direito Penal dentro do Estado Democrático de Direito não pode conferir à reserva legal um aspecto meramente formalista, apegado a uma descrição de delito desprovida de qualquer conteúdo lesivo. As condutas legalmente descritas devem estar marcadas pela ofensividade a interesses de relevância primária para a sociedade. O Direito Penal evolui. A infração penal não é mais vista como a simples realização da figura típica descrita na lei penal à qual se aplica uma sanção, sem que haja qualquer menção de que a conduta lesiona um interesse juridicamente tutelado. ${ }^{172}$

Portanto, a legalidade não é mais apenas um principio formal, devendo, pois, ser analisada também substancialmente. Não é a simples prática da conduta descrita previamente, por lei escrita, restrita e certa que pode ser considerada crime, tornando-se necessário que tal conduta cause, também, dano significativo ao bem tutelado.

Assim, quando da apreciação do crime, o desvalor do resultado não deve ser analisado separadamente do valor da ação e, em sendo ausentes estes, incide a insignificância.

\subsection{Princípio da fragmentariedade e subsidiariedade}

Atendo-se ao caráter fragmentário do Direito Penal, tem-se que nem todo bem jurídico recebe a tutela penal para sua proteção, assim como nem toda conduta lesiva a um bem jurídico é objeto de criminalização.

172 PRESTES, Cássio Vinícius D.C.V. Lazzari. O princípio da insignificância como causa excludente da tipicidade no direito penal. São Paulo: Memória Jurídica, 2003. p.53. 
Em magistral lição, Maurício Lopes bem sintetiza o conceito de fragmentariedade do direito penal:

O Direito Penal não foi construído com objetivos jurídicos de tutela que lhe fossem próprios ou exclusivos. Ao contrário, a sua formulação sempre esteve condicionada por um processo (ou por uma técnica) de eleição de bens jurídicos estranhos aos seus limites, captando-os e reconhecendo-os num sentido de importância informado por outros ramos do Direito.

A essa inexistência de objeto próprio e à consequência final desse processo de construção do sistema criminal sob uma escala de valores que não lhe é ontologicamente conhecida, mas imposta pelas circunstâncias de história, ética e padrão cultural de cada povo, dá-se o nome - ou erige-se a categoria fragmentariedade do Direito Penal. ${ }^{173}$

Com efeito, a fragmentariedade estabelece que os bens relevantes só devem ser penalmente defendidos diante de determinadas formas de agressões, consideradas socialmente intoleráveis. Assim, equivale dizer que somente as ações ou omissões mais graves, endereçadas contra bens valiosos, podem ser criminalizadas ${ }^{174}$, excluindo-se aquelas insignificantes, de ínfimo potencial lesivo ou de escassa ou nenhuma periculosidade.

Salienta-se que o princípio da insignificância, assim como o princípio da fragmentariedade, também funciona como um mecanismo de controle qualitativo e quantitativo, que norteia a intervenção penal, já que exige que a conduta do agente tenha certo grau de lesividade para ser considerada materialmente típica.

A diferença substancial entre os dois princípios reside no momento em que se dá o controle. A fragmentariedade é um principio politi-

${ }^{173}$ LOPES, Maurício Antônio Ribeiro. Princípio da insignificância no direito penal: analise à luz das leis 9.099/95, 9.503/97 (Código de Trânsito Brasileiro) e da jurisprudência atual. 2. ed. São Paulo: Ed. Revista dos Tribunais, 2000. p.65.

${ }^{174}$ GOMES, Luiz Flávio. Princípio da ofensividade do direito penal. São Paulo: Ed. Revista dos Tribunais, 2002. p. 92. 
co-criminal, dirigido ao legislador, que condiciona a elaboração do Direito Penal, porquanto o Princípio da Insignificância é uma fonte hermenêutica dirigida ao magistrado, informando a interpretação mais justa a ser aplicada pela lei penal.

De fato, o princípio da insignificância inspira-se no princípio da fragmentariedade e complementa a garantia oferecida por este, permitindo-se apontar o caráter fragmentário do Direito Penal como um dos seus fundamentos no caso concreto.

A positivação constitucional, embora seja condição necessária, não é suficiente para que um bem seja merecedor da tutela penal. Precisamente nesse ponto, o princípio da fragmentariedade é complementado pelo princípio da subsidiariedade.

Pode-se dizer que o principio da subsidiariedade decorre da fragmentariedade, já que a tutela penal apenas deve ter lugar quando as demais medidas coercitivas (cíveis ou administrativas) restarem inócuas e não surtirem efeito na missão de proteger o bem jurídico atacado.

Desse modo, reitera-se a premissa de que lei penal só deverá intervir quando for absolutamente necessário para o bem-estar da sociedade, como ultima ratio.

Luiz Regis Prado assevera que a subsidiariedade aparece como "orientação político-criminal restritiva do jus puniendi e deriva da própria natureza do Direito Penal e da concepção material de Estado de Direito Democrático", ${ }^{175}$ e complementa ao dizer que "o uso excessivo da sanção criminal (inflação penal) não garante uma maior proteção de bens; ao contrário, condena o sistema penal a uma função meramente simbólica e negativa". ${ }^{176}$

Corroborando com o exposto, tem-se o seguinte julgado:

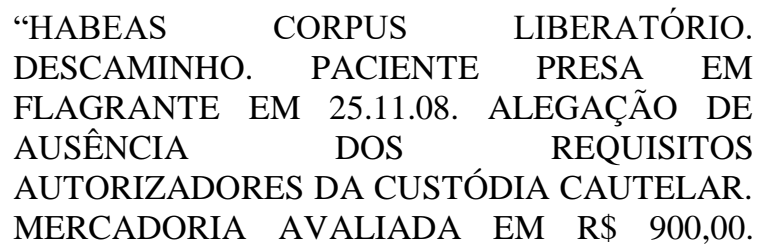

${ }^{175}$ PRADO, Luis Regis. Curso de direito penal brasileiro. 5 ed. São Paulo: Ed. Revista dos Tribunais, 2005. p. 149

${ }^{176}$ Idem. p. 149 
ATIPICIDADE DO FATO. PRECEDENTES STJ E STF. PARECER DO MPF PELA DENEGAÇÃO DO WRIT. ORDEM CONCEDIDA DE OFÍCIO PARA TRANCAR A AÇÃO PENAL, EXPEDINDO-SE O COMPETENTE ALVARÁ DE SOLTURA CLAUSULADO, SE POR OUTRO MOTIVO NÃO ESTIVER PRESO.1. A Terceira Seção desta Corte Superior entendeu, em relação ao crime de descaminho, ser aplicável o princípio da insignificância, quando o valor do tributo iludido ao Fisco Federal não ultrapassa 10.000,00 (art. 20 da Lei 10.522/02, alterado pela Lei 11.033/04), consoante a orientação emanada do colendo STF. 2. Esse entendimento funda-se na irrelevância da conduta da vítima, já que, in casu, o Estado dispensa, administrativamente, o direito ao crédito tributário, não havendo que se exigir a intervenção do Direito Penal, em vista da aplicação dos princípios da subsidiariedade, intervenção mínima e fragmentariedade. 3. Parecer do MPF pela denegação do writ. 4. Habeas Corpus concedido de ofício para trancar a Ação Penal, ante a atipicidade do fato, expedindo-se o competente alvará de soltura clausulado, se por outro motivo não estiver presa". (STJ HC 132.528/MS, Rel. Ministro NAPOLEÃO NUNES MAIA FILHO, QUINTA TURMA, julgado em 04/05/2010, DJe 07/06/2010) $)^{177}$

Portanto, percebe-se que sobre a criminalidade de bagatela devem incidir instrumentos de controle diversos do Direito Penal, ou seja, somente quando fracassados os demais ramos do direito, suscetíveis de resolução de conflitos, é que deve incidir o Direito Penal, como ultima ratio.

\subsection{Princípio da proporcionalidade}

${ }^{177}$ BRASIL. Superior Tribunal de Justiça. HC 132.528/MS. Rel. Ministro NAPOLEÃO NUNES MAIA FILHO, QUINTA TURMA, julgado em 04.05.2010. 
O princípio da insignificância encontra um de seus principais fundamentos no princípio da proporcionalidade, que preceitua que a pena a ser aplicada deve ajustar-se adequadamente à gravidade da lesão provocada.

Assim, sendo ínfima a afetação do bem jurídico resguardado pelo direito penal, não há que se falar em sanção penal, uma vez que qualquer penalidade - mesmo mínima - aplicada ao caso, será incompatível à significação social do fato.

Nos dizeres do professor Maurício Antonio Ribeiro Lopes:

De acordo com o princípio da proporcionalidade (poena debit commensurari delicto), deve existir sempre uma medida de justo equilíbrio - abstrata (legislador) e concreta (juiz) - entre a gravidade do fato praticado e a sanção imposta. Em suma, a pena deve estar proporcionada ou adequada à magnitude da lesão ao bem jurídico representada pelo delito e a medida de segurança à perigosidade criminal do agente. ${ }^{178}$

A proporcionalidade da pena evidencia duas exigências. De um lado tem por finalidade representar o interesse social em estabelecer uma reprimenda penal necessária e suficiente para reprovação e prevenção do crime, conforme o disposto no artigo 59 do Código Penal; de outro, visa a assegurar ao condenado o direito de não lhe ser imposta uma reprimenda além dos limites do mal produzido pela prática do ilícito. Assim, a proporcionalidade deve buscar a justa e adequada medida entre a punição aplicada e o mal praticado pelo agente.

Em verdade, o fundamento maior do princípio da insignificância está justamente nesta ideia de proporcionalidade que a pena deve guardar em relação à gravidade do crime.

Ora, nos casos de ínfima afetação ao bem jurídico, o conteúdo de injusto é tão irrisório que não subsiste razão alguma para o pathos ético da pena. Destarte, mesmo que haja a aplicação de uma pena mínima, esta seria descabida, pois desproporcional à significação social do fato.

${ }^{178}$ LOPES, Maurício Antonio Ribeiro. Princípios políticos de direito penal. São Paulo: Ed. Revista dos Tribunais, 1999. p. 91. 
Assim, o Princípio da Insignificância, ao excluir do campo de incidência do Direito Penal as condutas penalmente insignificantes, materializa o princípio da proporcionalidade, pois impede a ocorrência de eventual desproporcionalidade entre o fato praticado pelo agente e a consequente resposta penal que, caso aplicada, será demasiadamente exacerbada.

Bittencour também expressa essa correlação entre proporcionalidade e insignificância, ao dizer que, segundo este princípio, "é necessária uma efetiva proporcionalidade entre a gravidade da conduta que se pretende punir e a drasticidade da intervenção penal". ${ }^{179}$

Sob esse aspecto é que o princípio da insignificância concretiza a proporcionalidade existente entre o fato delituoso e a reação do Estado, objetivando, portanto, a obtenção da justiça em seu sentido material.

\subsection{Princípio da igualdade}

O princípio da igualdade é um dos instrumentos basilares do Estado Democrático de Direito, já que a Constituição Federal o adotou como modelo de organização jurídica e politica.

Por ser a Carta Magna uma norma superior e servir como base para a formulação das demais normas que integram a ordem jurídica, tem-se que o Direito Penal deve ser elaborado e interpretado em consonância com os princípios maiores que caracterizam o modelo de Estado.

Desta feita, o princípio da igualdade é consagrado na Constituição de 1988 em seu artigo $5^{\circ}$, caput, que dispõe que todos são iguais perante a lei, sem distinção de qualquer natureza.

A análise literal do dispositivo leva à inequívoca conclusão de que a Lei Maior reconheceu a igualdade em seu aspecto formal, no sentido de que a lei deve tratar a todos igualmente, sem considerar as desigualdades de situações ou grupos. Todavia, o mencionado artigo deve ser interpretado com enfoque material à igualdade, já que é cediço que a igualdade material implica tratar igualmente os iguais e desigualmente os desiguais na medida de suas desigualdades.

${ }^{179}$ BITENCOURT, Cezar Roberto. Manual de direito penal: parte geral. 6, ed. São Paulo: Saraiva, 2000. p. 218. 
Consigna-se que a lei penal diz respeito ao fato ilícito e não ao autor do delito; no entanto, no momento em que há a materialização do comportamento previsto abstratamente em lei, é função do aplicador do Direito Penal levar a efeito as desigualdades e as particularidades ocorridas em cada caso concreto para se garantir a equidade.

Neste contexto é o ensinamento de Cássio Vinícius Prestes, o qual diz que "configura patente injustiça a imposição da mesma pena aos autores do mesmo delito em homenagem a uma igualdade meramente abstrata" $" 180$.

Portanto, o principio da igualdade deve se inserir na insignificância para conferir uma dimensão material do delito no caso em concreto.

Para evitar que a igualdade perante a lei leve às injustiças em razão das desigualdades materiais, o magistrado deve adicionar ao Princípio da Igualdade um conteúdo material para sua efetivação. Assim, devese levar em consideração o desigual grau de ofensividade das condutas típicas praticadas, realizando, portanto, um juízo crítico sobre a utilidade e justiça de apenar-se determinada conduta insignificante, sob pena de provar um mal maior que o próprio delito praticado.

Desta feita, a aplicação do principio da insignificância, nas condutas penalmente irrelevantes, encontra respaldo no Princípio da Igualdade que, uma vez realizado materialmente, evita que o agente seja apenado mais do que exigido no grau de reprovabilidade de sua conduta típica.

\subsection{Princípio da liberdade}

O direito à liberdade consubstancia-se no reconhecimento jurídico de que todos os cidadãos têm autodeterminação individual que, em regra, não pode ser vedada pelo Estado. Em seu sentido amplo, a noção de liberdade de ação é chamada de liberdade matriz ou padrão.

Na Constituição da República Federativa do Brasil, a liberdade matriz ou padrão é manifestada em variados momentos, tais como: no preâmbulo do art. $5^{\circ}$, em que é expresso que o Estado Democrático brasi-

${ }^{180}$ PRESTES, Cássio Vinícius. O princípio da insignificância como causa excludente da tipicidade no Direito Penal. São Paulo: Memória Jurídica, 2003. p.47. 
leiro é "destinado a assegurar o exercício dos direitos sociais e individuais, a liberdade, a segurança, o bem-estar, o desenvolvimento, a igualdade e a justiça como valores supremos de uma sociedade"(...);

no inciso II, do mesmo artigo, o qual trata do princípio da legalidade geral, que expressa que "ninguém será obrigado a fazer ou deixar de fazer alguma coisa senão em virtude da lei" e

no artigo $3^{\circ}$, I, que estabelece como objetivo fundamental da República Federativa do Brasil "construir uma sociedade livre, justa e solidária.".

Essas repercussões incidem de várias maneiras no campo do Direito Penal.

Contudo, necessário dizer que, na seara penal, o aspecto da liberdade subsume-se à ideia de locomoção do indivíduo, a qual sempre, direta ou indiretamente, próxima ou remotamente, é atingida ou ameaçada pelo instituto da pena criminal.

Essa faceta da liberdade, incidente na norma penal, evidencia que a sociedade brasileira deve ser fundamentalmente livre. Não se confunde liberdade com impunidade, por evidente, mas a norma cogente revela uma tendência a adotar políticas criminais que atenuem a pena privativa de liberdade através de métodos alternativos ou substitutivos de sanção.

No que tange à correlação entre o principio da insignificância e o principio da liberdade, Ivan Luiz da Silva conclui com maestria que:

A aplicação do princípio da insignificância evita que agente de condutas penalmente insignificantes tenha a sua liberdade indevidamente atingida, concretizando, assim, o valor da liberdade individual, albergado pelo princípio da liberdade em nosso ordenamento jurídico. ${ }^{181}$

Assim, a aplicação do principio da insignificância limita a intervenção da pena criminal, valorizando o direito à liberdade do cidadão. Determina, outrossim, que o Direito Penal somente deve restringir esse

181 SILVA, Ivan Luiz da. Princípio da insignificância como excludente da tipicidade no direito penal. São Paulo: Saraiva, 1994. p. 124. 
direito fundamental de liberdade nos casos em que houver efetiva lesividade dos ilícitos.

Assim, a aplicação da bagatela evita que o agente de condutas penalmente insignificantes tenha sua liberdade ceifada, pois muitas vezes a aplicação da pena pode revelar-se mais prejudicial que o próprio delito cometido.

\subsection{Princípio da razoabilidade}

O Direito exige uma lógica própria na sua interpretação e integração e, por ser uma ciência de natureza social, não pode ser interpretado de modo inflexível, com base em fundamentos lógicos e puros, pois o formalismo intransigente o distancia da realidade humana, conduzindo a resultados indesejáveis de injustiça.

A razoabilidade implica a realização de operações de valoração e adaptação à realidade concreta, dando consistência à possibilidade material de realização da justiça quando da aplicação da lei, sobretudo a penal. Em consequência disso, a razoabilidade é erigida à categoria de princípio geral, informativo do sistema jurídico positivo.

Assim é que o princípio opera uma redução da normatividade positiva do Direito através de uma fixação criteriosa de métodos reconhecedores e desconhecedores da relevância ético-jurídica de fatos praticados, através de interpretação atual e ontológica da própria norma, individualmente considerada, e do Direito, como sistema. ${ }^{182}$

Diomar Ackel Filho salienta que, no caso da insignificância, "a interpretação com base em critérios de razoabilidade desconsidera um determinado fato como obra criminosa, valorando-o como insignificante e, portanto, destituído de reprovabilidade, de modo a obstar que possa subsumir num standart de tipicidade penal" ${ }^{183}$, podendo o fato, inclusive,

${ }^{182}$ LOPES, Maurício Antônio Ribeiro. Princípio da insignificância no direito penal: analise à luz das leis 9.099/95, 9.503/97 (código de trânsito brasileiro) e da jurisprudência atual. 2. ed. São Paulo: Ed. Revista dos Tribunais, 2000. p. 62. 183 ACKEL FILHO, Diomar. O princípio da insignificância no direito penal. Revista de Jurisprudência do Tribunal de Alçada Criminal de São Paulo. São Paulo: TJSP, 1988. p. 74. 
melhor se amoldar a ilícitos civis e/ou administrativos, esferas do direito amplamente competentes para dirimi-los.

\section{O PRINCÍPIO DA INSIGNIFICÂNCIA COMO EXCLUDENTE DA TIPICIDADE}

Hodiernamente, a maioria da doutrina e da jurisprudência tem situado o princípio da insignificância como um mensurador da tipicidade material.

Conforme restou demonstrado, o princípio da insignificância é um instrumento jurídico fundamentado nos preceitos constitucionais da legalidade, igualdade, liberdade, razoabilidade, fragmentariedade, subsidiariedade e proporcionalidade, e age como limite tático da norma penal, excluindo a tipicidade material nos delitos que afetam insignificantemente o bem jurídico tutelado pela norma.

Com efeito, pelo conceito analítico do delito, segundo Carlos Vico Mañas,

a conduta humana somente poderá ser considerada criminosa quando infringir o ordenamento jurídico (antijuricidade), na maneira prevista pelos tipos penais (tipicidade) e puder ser atribuída a seu autor (culpabilidade) $^{184}$.

Assim, não basta que uma conduta se ajuste a um determinado tipo penal para que, desde logo, seja tida como ilícita, capaz de ensejar uma sanção penal. Quando levada a efeito a prática criminosa do agente, deve haver a necessária comprovação da antijuricidade material da conduta, devendo ser configurada significativa lesão a determinado bem ou valor. Deste modo, em sendo a lesão resultante da conduta ilícita aquém do limite qualitativo-quantitativo exigível, não se justifica o reconhecimento do delito, tampouco a imposição de pena.

Odone Sanguiné, citado por LOPES, assevera com precisão o conteúdo da tipicidade material:

${ }^{184}$ MAÑ̃̃S, Carlos Vico. A concepção material do tipo penal. Revisa da Procuradoria Geral do Estado de São Paulo, no 30, dez. 1988, p. 148. 
A tipicidade não se esgota na concordância lógicoformal (subsunção) do fato no tipo. A ação descrita tipicamente há de ser geralmente ofensiva ou perigosa a um bem jurídico. O legislador toma em consideração modelos de vida que deve castigar. Com essa finalidade, tenta compreender, conceitualmente, da maneira mais precisa, a situação vital típica. Embora visando a alcançar um circulo limitado de situações, a tipificação falha ante a impossibilidade de regulação do caso concreto em face da infinita gama de possibilidades do acontecer humano. Por isso, a tipificação ocorre conceitualmente de forma absoluta para não restringir demasiadamente o âmbito da proibição, razão por que alcança também casos anormais. A imperfeição do trabalho legislativo não evita que sejam subsumíveis também nos casos que, em realidade, deveriam permanecer fora do âmbito de proibição estabelecido pelo tipo penal. A redação do tipo penal pretende, por certo, somente incluir prejuízos graves da ordem jurídica e social, porém não pode impedir que entrem em seu âmbito os casos leves. Para corrigir essa discrepância entre o abstrato e o concreto, e para dirimir a divergência entre o conceito formal e o conceito material do delito, importante utilizar-se o princípio da insignificância. A solução através do recurso à atipicidade quando a lesão ao bem jurídico tenha sido irrelevante é a predominante na Alemanha. ${ }^{185}$

Portanto, o tipo deve, necessariamente, ser entendido como um mecanismo dotado de conteúdo valorativo, não devendo ser analisado apenas sob a ótica formal, de cunho eminentemente diretivo, para que se possa ter um verdadeiro juízo de tipicidade, sem atingir fatos que, por serem aceitos socialmente ou não causarem dano social relevante, devem ser estranhos ao Direito Penal, devido a sua efetiva insignificância.

${ }^{185}$ LOPES, Maurício Antônio Ribeiro. Princípio da insignificância no direito penal: analise à luz das leis 9.099/95, 9.503/97 (código de trânsito brasileiro) e da jurisprudência atual. 2. ed. São Paulo: Ed. Revista dos Tribunais, 2000. P. 35 
Neste sentido, aliás, é o entendimento do extinto Tribunal de Alçada Criminal de São Paulo:

Assim, a consequência natural da aplicação do principio da insignificância será a exclusão da punibilidade das infrações penais de pouca importância ou ínfima lesividade. A ideia central é que este tipo de conduta não deve ser considerada penalmente típica, embora se encaixe formalmente em uma descrição típica, contenha desvalor jurídico, não seja justificada, nem plenamente lícita.(Ap. 988.073-2, TACrimSP, $10^{\text {a }}$ Câm., Rel. Juiz Márcio Bártoli, j. 03.01.1996. Revista dos Tribunais, $85^{\circ}$ ano, v. 733, nov. 1996, p. 580).

Capez comenta que "se a finalidade do tipo penal é tutelar um bem jurídico, sempre que a lesão for insignificante, a ponto de se tornar incapaz de lesar o interesse protegido, não haverá adequação típica"186.

Assim, deve-se dizer que o conceito material de tipo reflete diretamente na descriminalização das condutas que, mesmo formalmente típicas, não constituem efetiva ameaça aos bens jurídicos penalmente tutelados.

Por fim, faz-se imperioso registrar que, para restar devidamente configurada a tipicidade material, deve-se ter por evidente duas modalidades de desvalor, que ora pode residir na conduta, ora no resultado.

\section{CRÍTICAS}

Muito embora o princípio da insignificância seja aceito pela maioria da doutrina e jurisprudência, ainda existem correntes que se opõem à sua aplicação.

Em razão do princípio da insignificância não encontrar previsão legislativa, sendo, pois, uma criação doutrinária e, sobretudo, jurisprudencial, muitos doutrinadores e aplicadores do direito a ele se opõem,

${ }^{186}$ CAPEZ, Fernando. Curso de direito penal: parte geral. 6 ed. São Paulo: Saraiva, 2003. p. 10-13. 
alegando, ademais, sua contribuição para a edificação de um estado de profunda insegurança jurídica.

A referida crítica deve ser rechaçada de plano, pois, muito embora não esteja positivado na lei escrita, incontroverso admitir que o princípio da insignificância surge como recurso teleológico para integração semântica e política do Direito Penal, já que, como se sabe, a norma escrita não contém todo este Direito. Salienta-se, ainda, que a construção teórica de princípios, como o da insignificância, não fere o mandamento constitucional da legalidade ou reserva legal.

Destarte, outros pensadores ainda reclamam que o estudado princípio padece de uma imprecisão terminológica. Isso porque não se consegue desvinculá-lo de uma conotação excessivamente politica e ideológica, sendo campo de embate de diversas correntes de pensamentos. Ou, ainda, que o princípio não está dotado de uma força motriz autônoma, já que se funda em valores interiores que justificam por sua própria natureza a importância no sistema, sendo mero apêndice do desvalor de resultados lesivos concretamente verificáveis. ${ }^{187}$

Ambas as críticas não merecem prosperar. Ora, o princípio da insignificância, como visto, opera como limite tático da norma penal, isto é, a perceptibilidade da agressão ao bem é considerada como requisito implícito do crime, em ausência do qual, no caso concreto, a pena não se legitima nem sob o perfil substancial nem sob o perfil ideológico. ${ }^{188}$

Ainda acerca do principio da insignificância, há críticas no sentido de que já existem previsões legislativas residuais que expressam um desvalor de resultado quando for necessário. É o caso brasileiro, onde o Código Penal prevê figuras privilegiadas ou com causa de diminuição de pena quando for necessário, dentre as quais o furto de coisa de pequeno valor (art. $155, \S 2^{\circ}$ do $\mathrm{CP}$ ), a apropriação de coisa de pequeno valor, (art. 170 do $\mathrm{CP}$ ), o estelionato onde há pequeno prejuízo da vítima (art. 171, $\S 1^{\circ}$ do $\mathrm{CP}$ ) e a receptação de coisas idênticas (Art. $180, \S 3^{\circ}$ do $\mathrm{CP}$ ). Ademais, encontra-se em vigor, ainda, a lei de contravenções penais, que nada mais é senão um vasto repertório de infrações penais reputadas de menor gravidade.

${ }^{187}$ LOPES, Mauricio Antônio Ribeiro. Principio da insignificância no direito penal. São Paulo: Ed. Revista dos Tribunais, 1997. p.173.

${ }^{188}$ LOPES, Mauricio Antônio Ribeiro. Principio da insignificância no direito penal. São Paulo: Ed. Revista dos Tribunais, 1997. p.173. 
Tremendo equivoco daqueles que assim acreditam. Consigna-se que nada impede que, feita à valoração normativa da ofensa, nos moldes anteriormente sugeridos, o interpretante reconheça que, de tão ínfima a afetação, não se subsume sequer aos tipos privilegiados ou contravencionais. ${ }^{189}$

Assim, ausente o critério de necessidade permanente, o fato deverá ser tido como alheio ao interesse penal. Faltando o critério de necessidade momentânea, o fato deve ser tido como justificável por causa excludente de um dos elementos do crime. Por fim, ausente o critério da necessidade da pena, tem-se o fato por merecedor de indulgência pelo Magistrado.

Portanto, não prosperam as críticas feitas ao princípio da insignificância, visto que a norma penal não deve se ater ao seu formalismo exacerbado, mas sim atender às minúcias do caso concreto a fim de atingir a justiça.

Em razão do caráter subsidiário e fragmentário do Direito Penal, este deve ser utilizado como ultima ratio pelo Estado, a fim de inibir condutas destoantes da sociedade, que causam riscos concretos à vida em comum, não devendo, pois, ater-se em aplicar sanções àquelas condutas que estão aquém da reprovabilidade social, ou que causem ínfima lesão ao bem jurídico resguardado pela norma penal.

\section{CONSIDERAÇÕES FINAIS}

Com o estudo do presente artigo tornou-se possível delimitar o aspecto histórico, os fundamentos jurídicos e a abrangência do princípio da insignificância, o qual sem dúvida tem-se mostrado um importante instrumento jurídico garantidor da justiça no caso concreto.

Embora haja divergência doutrinária quanto à existência histórica do princípio, não se pode olvidar que os Romanos contribuíram para a sua formação, que foi estancada na máxima "mínima non curat preator". Porém, deve-se consignar que o enfoque mais assíduo sobre a matéria deu-se principalmente após a Segunda Guerra Mundial, momento em que houve uma eclosão dos pequenos furtos, marcados pelos saques nas cida-

${ }^{189}$ Idem. p. 175. 
des que, contudo, não atingiam sobremaneira o patrimônio, e tampouco a conduta típica do agente sofria grande aversão social.

Em 1964, Claus Roxin, importante doutrinador alemão, foi o primeiro a conceituar e delimitar o princípio da insignificância com maior propriedade, sustentando que, em sendo a lesão insignificante, não há necessidade de se aplicar uma pena, pois não se trata de fato punível.

Neste contexto, necessário registrar que a norma penal somente deve destinar-se à proteção de determinados bens jurídicos - os mais relevantes - e contra determinadas formas de agressão, já que possui um caráter subsidiário e fragmentário.

Assim, a insignificância surge como princípio, isto é, como disposição fundamental do sistema, assentada principalmente no princípio da legalidade, da equidade e da razoabilidade, tendo surgido em função do excesso de delitos irrelevantes com caráter patrimonial. Contudo, em razão de ser um princípio geral do Direito Penal, a bagatela deve ser aplicada a todos os bens jurídicos penalmente tutelados.

Apesar de não haver previsão no ordenamento jurídico, a aceitação do princípio da insignificância é cada vez maior nos Tribunais Pátrios. Contudo, ainda ocorrem casos vergonhosos, em que se ignora a bagatela, causando resultados e danos irreversíveis ao indivíduo com aplicação de uma pena.

O princípio da insignificância tem suporte na premissa de que o Direito Penal não deve se ater às condutas de pequena monta, que não causam danos sociais ou materiais preponderantes, em detrimento de condutas efetivamente danosas e que provocam desequilíbrio efetivo nas relações jurídicas em sociedade.

Em síntese, a insignificância funciona como uma recomendação geral aos operadores do direito, em especial aos membros do Ministério Público e aos julgadores em todas as instâncias, para que não se detenham na dedicação de incriminar condutas de pouca ou nenhuma expressão econômica ou social.

Consigna-se que, para aplicação da norma penal, deve-se levar a efeito o fato de que a tipicidade, para restar configurada, exige uma significativa ofensa aos bens jurídicos protegidos, pois nem sempre qualquer ofensa a esses bens ou interesses é suficiente para se configurar o injusto típico. Segundo o princípio aqui tratado, é imperativa uma efetiva proporcionalidade entre a gravidade da conduta punível e a drasticidade da intervenção estatal, sendo que a insignificância só pode ser valorada através 
da consideração global da ordem jurídica, observando-se as particularidades do caso, em especial o grau ou a extensão da lesão sofrida pelo bem jurídico resguardado. Neste ínterim, uma infração de menor potencial ofensivo pode ou não caracterizar a insignificância, dependendo exatamente da gravidade do dano sofrido pelo bem atingido.

Imperioso registrar que o STF, no intuito de dirimir os conflitos acerca da aplicação da insignificância, impingiu requisitos de abrangência ao princípio, quais sejam: mínima ofensividade da conduta do agente; nenhuma periculosidade social da ação; reduzido grau de reprovabilidade do comportamento; e inexpressividade da lesão jurídica provocada.

Assim, em sendo configurados todos os requisitos retromencionados, como medida de equidade, deve o magistrado, ao sentenciar, aplicar o principio da insignificância como uma excludente da tipicidade, em razão da inexistência de tipicidade material da conduta, em razão do bem jurídico sofrer ínfima afetação.

Por fim, pode-se concluir que o princípio da insignificância é um instrumento da política criminal por meio da qual algumas condutas consideradas inicialmente típicas podem ser excluídas da apreciação do Direito Penal, dada a irrelevância da ofensa ao bem jurídico tutelado pelo Estado.

\section{REFERÊNCIAS BIBLIOGRÁFICAS}

ACKEL FILHO, Diomar. O princípio da insignificância no direito penal. Revista de jurisprudência do tribunal de alçada criminal de São Paulo. TJSP, 1988, v. 94.

ARRUDA, Élcio. Insignificância: um princípio nada insignificante. Boletim IBCCRIM : São Paulo, ano 17, n. 202, p. 12-14, set. 2009.

BITENCOURT, Cezar Roberto. Manual de direito penal: parte geral. 6, ed. São Paulo: Saraiva, 2000.

BRASIL. Supremo Tribunal Federal. HC n. 94.505/RS. Habeas Corpus.

Rel. Ministro CELSO DE MELLO, julgado em 16.9.2008.

BRASIL. Superior Tribunal de Justiça. HC n. 67.905/SP, Rel. Ministro ARNALDO ESTEVES LIMA, julgado em 7.8.2008

BRASIL. Superior Tribunal de Justiça. HC 132.528/MS. Rel. Ministro NAPOLEÃO NUNES MAIA FILHO, julgado em 04.05.2010. 
CAPEZ, Fernando. Curso de direito penal: parte geral.6. ed. São Paulo: Saraiva, 2003.

GOMES, Luiz Flávio. Princípio da ofensividade do direito penal. São Paulo: Ed. Revista dos Tribunais, 2002.

LOPES, Maurício Antônio Ribeiro. Princípio da insignificância no direito penal: análise à luz da lei 9.099/95 - Juizados Especiais Criminais e da jurisprudência atual. São Paulo: Revistas dos Tribunais, v. 2, 1997.

. Princípios políticos de direito penal. São Paulo: Ed. Revista dos Tribunais, 1999.

. Princípio da insignificância no direito penal: analise à luz das leis 9.099/95, 9.503/97 (código de trânsito brasileiro) e da jurisprudência atual. 2. ed. São Paulo: Ed. Revista dos Tribunais, 2000.

MAÑAS, Carlos Vico. O princípio da insignificância como excludente de tipicidade no direito penal. São Paulo: Saraiva, 1994.

A concepção material do tipo penal. Revista da Procuradoria Geral do Estado de São Paulo, no ${ }^{\circ}$ 30, dez. 1988.

PRADO, Luiz Regis. Bem Jurídico- Penal e Constituição. $2^{\text {a }}$. ed. São Paulo: Revista dos Tribunais, 1997.

PRESTES, Cássio Vinícius D.C.V. Lazzari. O princípio da insignificância como causa excludente da tipicidade no direito penal. São Paulo: Memória Jurídica, 2003.

ROXIN, Claus. Política Criminal e Sistema Jurídico-Penal, tradução Luís Greco. São Paulo: Editora Renovar, 2000.

SILVA, Ivan Luiz da. Princípio da insignificância no direito penal brasileiro. Curitiba: Juruá, 2006.

. Princípio da insignificância como excludente da tipicidade no direito penal. São Paulo: Saraiva, 1994.

TOLEDO, Francisco de Assis. Princípios básicos de direito penal: de acordo com a lei ${ }^{\circ} 7209$, de 11-7-1984 e com a Constituição Federal de 1988. 4 ed. São Paulo: Saraiva, 1991. 
